\section{SYNTHESIS OF THE DECARBOXY ANALOG OF EDEINE D*}

\section{J. Gumieniak, R. ANDRUSZKiewicz,} A. Czerwiński, J. Grzybowska and E. BorowskI

Department of Pharmaceutical Technology and Biochemistry, Technical University, 80-952 Gdańsk, Poland

(Received for publication April 12, 1983)

In the course of our studies on structurebiological activity relationships among the antibiotics of the edeine group it was demonstrated, that esters and amides of edeine A exhibit antimicrobial activities comparable with that of parent antibiotic ${ }^{1)}$. These results pointed to a negligible contribution by the free ionizable carboxyl group to the antibiotic activity manifested by edeines. For further evidence we have synthesized the decarboxy analog of edeine $\mathbf{D}$ (II) by replacing the $[2 R, 6 S, 7 R]$-2,6-diamino-7-hydroxyazelaic acid ( $\mathrm{A}_{2}$ ha $)$ moiety present in native edeine D $(\mathbf{I})^{2,3)}$ with $[3 R, 4 S]-4,8$-diamino-3-hydroxyoctanoic acid $\left(\mathrm{A}_{2}\right.$ ho) as shown on Fig. 1.

The synthesis of decarboxy-edeine $\mathrm{D}$ was performed according to Scheme 1 presented below.

$[3 R, 4 S]-N^{4}-t$ - Butyloxycarbonyl- $N^{8}$-benzyloxycarbonyl-4,8-diamino-3-hydroxyoctanoic acid ethyl ester (1) synthesized from $S$-lysine by modified Steulmann method ${ }^{4}$ was converted to corresponding acid 2 by saponification with $\mathrm{KOH}$ in methanol and coupled with Gly-Spe(Boc) ${ }_{2}{ }^{\mathrm{b}}$ by means of diphenylphosphorazidate (DPPA) ${ }^{\text {e }}$ to give the protected dipeptide amide 3. After hydrogenolysis of $\mathbf{3}$ in presence of palladium on charcoal the dipeptide amide with free primary amino group 4 was obtained. This was coupled with the protected tripeptide Z- $\beta$-Phe-Ise- $\mathrm{A}_{2} \mathrm{pr}^{\text {( ) }}$

Fig. 1. Chemical structure of edeine D (I) and its decarboxy analog (II).

1

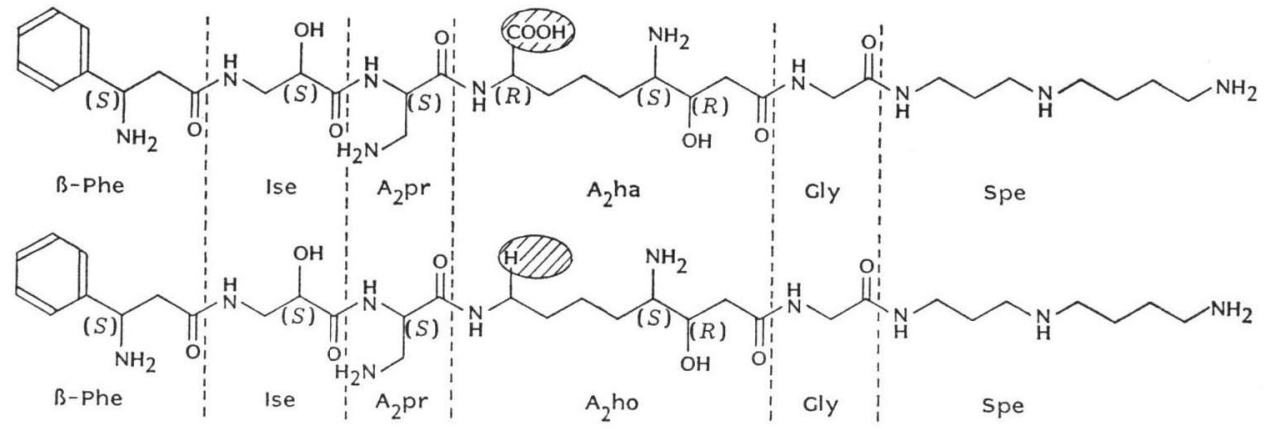

Scheme 1.

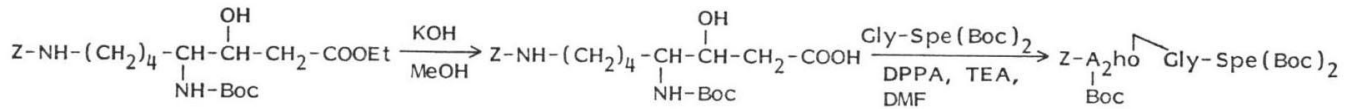

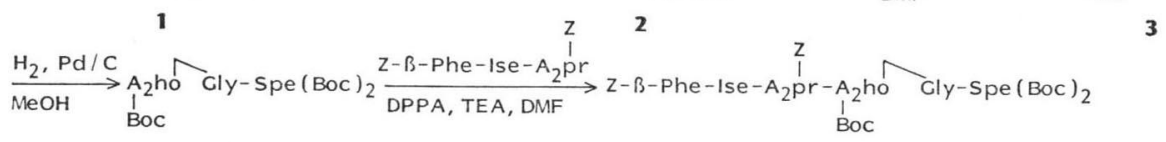

$$
\begin{aligned}
& 1 \mathrm{H}_{2}, \mathrm{Pd} / \mathrm{C} \quad 5 \\
& \underset{2 \mathrm{H}_{2} \mathrm{SO}_{4}}{2} \mathrm{HCOOH} \text {-Phe-Ise- } \mathrm{A}_{2} \mathrm{Pr}-\mathrm{A}_{2} \mathrm{ho} \text { Cly- } \mathrm{Spe} \cdot 2 \mathrm{H}_{2} \mathrm{SO}_{4} \text { (Decarboxyedeine D sulfate) }
\end{aligned}
$$

* Abbreviations: $\mathrm{Z}=\mathrm{C}_{6} \mathrm{H}_{5}-\mathrm{CH}_{2}-\mathrm{O}-\mathrm{C}-, \mathrm{Boc}=\left(\mathrm{CH}_{3}\right)_{3} \mathrm{C}-\mathrm{O}-\mathrm{C}-$, DPPA $=\left(\mathrm{C}_{6} \mathrm{H}_{5}\right)_{2} \mathrm{P}-\mathrm{N}_{3}, \mathrm{TEA}=$ triethylamine, $\stackrel{\|}{\mathrm{O}} \stackrel{\|}{\mathrm{O}} \stackrel{\|}{\|}$

$\mathrm{DMF}=$ dimethylformamide, $\mathrm{Gly}=$ glycine, $\mathrm{Spe}=$ spermidine, $\beta$-Phe $=\beta$-phenyl- $\beta$-alanine, Ise $=$ isoserine, $\mathrm{A}_{2} \mathrm{pr}$ $=\alpha, \beta$-diaminopropionic acid, $\mathrm{A}_{2}$ ha $=2,6$-diamino-7-hydroxyazelaic acid, $\mathrm{A}_{2} \mathrm{ho}=4,8$-diamino-3-hydroxyoctanoic acid. 
Table 1. Inhibitory concentration $\left(\mathrm{IC}_{50}\right)$ of edeine $\mathrm{D}$ and its decarboxy analog.

\begin{tabular}{lccc}
\hline & \multicolumn{3}{c}{$\begin{array}{c}\text { Inhibitory concentration } \\
\text { IC }\end{array}$} \\
\cline { 2 - 4 } Compound & $\begin{array}{c}\text { Saccharo- } \\
\text { myces } \\
\text { cerevisiae }\end{array}$ & $\begin{array}{c}\text { Bacillus } \\
\text { subtilis }\end{array}$ & $\begin{array}{c}\text { Escheri- } \\
\text { chia } \\
\text { coli }\end{array}$ \\
\hline Edeine D & 13 & 41 & 58 \\
Decarboxyedeine D & 27 & 7 & 10 \\
\hline
\end{tabular}

to afford $\mathbf{5}$, decarboxy-edeine $\mathrm{D}$ in protected form. Removal of the $t$-butyloxycarbonyl and benzyloxycarbonyl protecting groups by hydrogenation in $98 \%$ formic acid was followed by the addition of a stoichiometric amount of dilute sulfuric acid and isolation of decarboxy edeine $\mathrm{D}$ sulfate (6).

The activities of the decarboxyedeine $\mathrm{D}$ and native edeine $\mathrm{D}$ against selected microorganisms were determined by serial dilution in a liquid medium and are listed in Table 1.

The biological activity of decarboxyedeine D demonstrates that the carboxyl group of edeines does not participate in the interaction of the antibiotic with its cellular target.

\section{Experimental}

All melting points are uncorrected, TLC was performed on DC-Alufolien Kieselgel 60 "Merck". Biological activity determinations were carried out according to the method described previously ${ }^{1,8)}$.

[3R,4S]- $N^{4}$ - $t$ - Butyloxycarbonyl - $N^{8}$ - benzyloxycarbonyl - 4,8 - diamino - 3 - hydroxyoctanoic Acid (Z-A ho(Boc)) (2)

A solution of $0.45 \mathrm{~g}(1 \mathrm{mmol})$ of $(3 R, 4 S)-N^{4}$ $t$ - butyloxycarbonyl- $N^{8}$-benzyloxycarbonyl - 4,8 diamino-3-hydroxyoctanoic acid ethyl ester (Z$\mathrm{A}_{2}$ ho(Boc)-OEt, 1) in $10 \mathrm{ml}$ of methanol and $1.2 \mathrm{ml}$ of $1 \mathrm{M} \mathrm{KOH}$ aq. was allowed to stand at room temperature for 3 hours. Then mixture was concentrated under reduced pressure to $3 \mathrm{ml}$ diluted to $10 \mathrm{ml}$ with water, acidified with $5 \%$ aq. citric acid and extracted with ethyl acetate $(2 \times 10 \mathrm{ml})$. The combined extracts were washed with water $(5 \mathrm{ml})$, dried over $\mathrm{MgSO}_{4}$ and evaporated to dryness. The residue was crystallized from a mixture of ethyl acetate and $n$-hexane to yield $0.36 \mathrm{~g}(85 \%)$ of white crystals with $\mathrm{mp}$ $125 \sim 126^{\circ} \mathrm{C} . \quad \mathrm{Rf}=0.1$ in $n$-hexane - EtOAc $\mathrm{MeOH}, 7: 2: 1$; Rf 0.8 in EtOAc $-\mathrm{MeOH}-\mathrm{H}_{2} \mathrm{O}$,
500: 100: 75 .

Anal. Calcd. for $\mathrm{C}_{21} \mathrm{H}_{32} \mathrm{~N}_{2} \mathrm{O}_{7}(\mathrm{MW}=424.5)$ :

C 59.4, H 7.6, N 6.6.

Found: C 59.3, H 7.5, N 6.5.

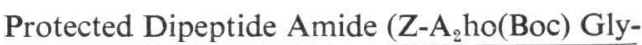
$\left.\mathrm{Spe}(\mathrm{Boc})_{2}\right)(3)$

To $0.212 \mathrm{~g}(0.5 \mathrm{mmol})$ of 2 and $0.29 \mathrm{~g}(0.7 \mathrm{~m}-$ mol) of protected glycylspermidine (Gly-Spe $\left.(B \circ)_{2}\right) 3$ dissolved in $5 \mathrm{ml}$ of DMF and cooled in ice bath, $0.14 \mathrm{~g}(0.5 \mathrm{mmol})$ of DPPA and $0.1 \mathrm{ml}$ $(0.7 \mathrm{mmol})$ of TEA were added with stirring. After standing overnight at room temperature the reaction mixture was diluted with ethyl acetate $(40 \mathrm{ml})$, washed with $5 \%$ aqueous citric acid, a $5 \%$ solution of sodium hydrogen carbonate, with water and dried over $\mathrm{MgSO}_{4}$. After evaporation of solvent and crystallization of the residue from ethyl acetate - ethyl ether $0.35 \mathrm{~g}(87 \%)$ of the protected peptide 3 was obtained with $\mathrm{mp}$ $80 \sim 81^{\circ} \mathrm{C}$. Rf 0.7 in EtOAc $-\mathrm{MeOH}-\mathrm{H}_{2} \mathrm{O}$, 500: $100: 75$.

Anal. Calcd. for $\mathrm{C}_{40} \mathrm{H}_{88} \mathrm{~N}_{8} \mathrm{O}_{11}(\mathrm{MW}=809.0)$ :

C 59.4, H 8.5, N 10.4.

Found: C 59.3, H 8.4, N 10.3.

Protected Decarboxyedeine D (5)

A solution of $0.18 \mathrm{~g}(0.22 \mathrm{mmol})$ of the protected peptide 4 in $10 \mathrm{ml}$ of methanol was hydrogenolyzed over $0.05 \mathrm{~g} \mathrm{Pd} / \mathrm{C}$ catalyst for 3 hours. The catalyst was filtered off, the solvent evaporated and product dissolved in $5 \mathrm{ml}$ of DMF. To this solution $0.12 \mathrm{~g}(0.20 \mathrm{mmol})$ of protected tripeptide (Z- $\beta$-Phe-Ise- $A_{2}$ pr) $\mathbf{5}$ and after cooling $\mathrm{Z}$

to $0^{\circ} \mathrm{C} 0.056 \mathrm{~g}(0.2 \mathrm{mmol})$ of DPPA and $0.05 \mathrm{ml}$ $(0.3 \mathrm{mmol})$ of TEA were added. After 24 hours the reaction mixture was worked up as described for 3. The oily residue triturated with ethyl ether yielded $0.15 \mathrm{~g}(60 \%)$ of the protected decarboxyedeine $\mathrm{D}(5)$ with $\mathrm{mp} 163 \sim 165^{\circ} \mathrm{C}$. Rf 0.6 in EtOAc - MeOH - $\mathrm{H}_{2} \mathrm{O}, 500$ : 100: 75.

$$
\begin{gathered}
\text { Anal. Calcd. for } \mathrm{C}_{83} \mathrm{H}_{95} \mathrm{~N}_{10} \mathrm{O}_{17}(\mathrm{MW}=1,264.5) \text { : } \\
\text { C 59.8, H 7.6, N 11.1. } \\
\text { Found: } \quad \text { C 59.7, H 7.5, N 11.0. }
\end{gathered}
$$

Decarboxyedeine D Sulfate (6)

A sample, $0.126 \mathrm{~g}(0.1 \mathrm{mmol})$, of the protected peptide 5 was dissolved in $5 \mathrm{ml}$ of $98 \%$ formic acid and hydrogenated over $0.05 \mathrm{~g}$ of $\mathrm{Pd} / \mathrm{C}$ catalyst within 10 hours. The catalyst was filtered off, the filtrate treated with $2.5 \mathrm{ml}$ of $0.1 \mathrm{M} \mathrm{H}_{2} \mathrm{SO}_{4}$ and evaporated to a small volume $(3 \mathrm{ml})$. The solution was dropped into a chilled mixture of ethanol 
and ether. The precipitate was centrifuged, washed with acetone, ether and dried under reduced pressure to yield $0.06 \mathrm{~g}(64 \%)$ of decarboxyedeine D sulfate (6). Rf 0.27 in $2-\mathrm{PrOH}$ $25 \% \mathrm{NH}_{3}$ aq. $-\mathrm{H}_{2} \mathrm{O}, 6: 4: 3$ (for edeine D 0.55); Rf 0.25 in $1-\mathrm{BuOH}$ - pyridine - $\mathrm{AcOH}-\mathrm{H}_{2} \mathrm{O}, 6$ : $2: 3: 5$ (for edeine D 0.22 ); Rf 0.38 in $1-\mathrm{PrOH}$ $25 \% \mathrm{NH}_{3}$ aq. - $\mathrm{CHCl}_{3}, 12: 8$ : 1 (for edeine $\mathrm{D} 0.39$ ). Paper electrophoresis (buffer: pyridine - $\mathrm{AcOH}$ $\mathrm{H}_{2} \mathrm{O}, 10: 100: 890, \mathrm{pH} 3.5,43 \mathrm{~V} / \mathrm{cm}, 40$ minutes): migration toward cathode $19.7 \mathrm{~cm}$ (for edeine D $16.3 \mathrm{~cm}$ ).

Anal. Calcd. for $\mathrm{C}_{32} \mathrm{H}_{58} \mathrm{~N}_{10} \mathrm{O}_{7} \cdot 2 \mathrm{H}_{2} \mathrm{SO}_{4} \cdot 3 \mathrm{H}_{2} \mathrm{O}$ $(\mathrm{MW}=945.1): \quad \mathrm{C} 40.7, \mathrm{H} 7.3, \mathrm{~N} 14.8$. Found: $\quad$ C $40.9, \mathrm{H}$ 7.5, N 14.9.

\section{Acknowledgment}

The authors acknowledge financial support by the Nencki Institute of Experimental Biology, the Polish Academy of Sciences, Warsaw. We are also indebted to Dr T. ZIENIAWA for the determination of biological activities.

\section{References}

1) MaZerski, J.; H. WojciechowsKa, W. Zgoda, B. WOYNAROWSKA \& E. BOROWSKI: Esters and amides of edeine A. J. Antibiotics 34: 28 33, 1981

2) WoJCIECHOWSKa, H.; R. ANDRUsZkiewicz, J. Grzybowska, A. CZerwiński, J. GUMieniak,
J. MAZERSKI, W. ZgODA \& E. BorowsKI: Total synthesis of edeine antibiotics and their analogs. Vol. 3, pp. 36 39, Proc. 11th IUPAC Intern. Symp. on Chemistry of Natural Products; Golden Sands, Bulgarian Academy of Sciences, 1978

3) GuMieniak, J.; H. WOJCiechowsKa \& E. Borowski: The antibiotic edeine. $\mathrm{X}$. The absolute configuration of 2,6-diamino-7-hydroxyazelaic acid. Polish J. Chem. 55: 1519 1526, 1981

4) GumieniaK, J.; R. ANDRUSZKIEWICZ \& E. BOROwSKI: Synthesis of edeine and their analogs. V. Synthesis of the protected $[3 R, 4 S]-4,8$-diamino-3hydroxyoctanoic acid. Monatshefte für Chemie, submitted.

5) ANDRUSZKIEWICZ, R.; H. WOJCIECHOWSKA \& E. BoRowski: Syntheses of edeine antibiotics and their analogs. I. Synthesis of $N$-(3-aminopropyl)- $N, N^{\prime}$-di- $t$-butyloxycarbonyl-1,4-diaminobutane. Polish J. Chem. 52: 1167 1172, 1978

6) Shiotri, T.; K. Ninomiya \& S. Yamada: Diphenylphosphorylazide. A new convenient reagent for a modified CuRTIUs reactions and for the peptide syntheses. J. Am. Chem. Soc. 94: 6203 6205, 1972

7) GrzybowsKa, J.; H. WojciechowsKa, R. ANDRUSZKIEWICZ \& E. BoRowSKI: Syntheses of edeine antibiotics and their analogs. IV. Synthesis of $\mathrm{N}$-terminal peptide fragments corresponding to active and inactive isomers of edeine D. Polish J. Chem. 53: 1533 1539, 1979

8) CZERWińsKi, A.; H. WOJCIECHOWSKA, R. Andruszkiewicz, J. GrzybowsKa, J. GumiENIAK \& E. BOROwSKI: Total synthesis of edeine D. J. Antibiotics 36: 1001 1006, 1983 